\title{
MADCAM1 Gene
}

National Cancer Institute

\section{Source}

National Cancer Institute. MADCAM1 Gene. NCI Thesaurus. Code C122912.

This gene plays a role in leukocyte migration. 